\title{
Further Exploration of the Thought of Self-reliance with the Concept of Compensation and Vocation
}

\author{
Haijing Liang \\ School of Foreign Language, Qingdao University of Science and Technology, Qingdao, China
}

\begin{abstract}
Ralph Waldo Emerson is a theorist of active self-reliance as the search for power and the energy; he is also a theorist of compensation. This is a complex idea on Emerson's version. The most relevant aspect of it for the way of life is compensation as the fate that must be endured by an actively self-reliant individual prone to repeated efforts of ever more ample self-definition. The net result of the law of compensation is that the adventurous or experimental person is overtaken. He or she is encircled, limited, thrown back. From one perspective, there is no progress, no ascendant movement, no breaking out. If what is circular is compensatory, it is not progressive.
\end{abstract}

Index Terms - self-reliance, individualism, compensation, vocation

\section{A COMPLEX IdEA OF SelF-RELIANCE--COMPENSATION}

\section{A. The Theory of Compensation Reassuring that Every Wrong Done Is Paid for}

In Compensation, Emerson struggles to put forth the moral idea of compensation. Its preponderant effect is a qualification of his exuberance, even though it also attempts to convert despair into hope. Emerson includes within the theory of compensation the reassurance that every wrong done is paid for, just as every is rewarded, and every unlucky disadvantage has a corresponding strength. The world is a compensatory economy of inflexible justice. "Justice is not postponed. A perfect equity adjusts its balance in all parts of life" (Emerson, 1979, p.58). "Retribution is scarcely distinguishable from being. There is a crack in everything God has made" (Emerson, 1979, p.58). Yet at the same time, there is "the deep remedial force that underlies all facts" (Emerson, 1979, p.60). Emerson brings his point home in the language of business when he speaks of the subtle and inextricable compensation that attaches to property: "Everything God hath made has the two faces. Every cent in a dollar covers its worth and also covers its evil if so much property, then so much risk, if so much power, then so much danger, if so much revenue, then so much tax. All property must and will pay its tax. If it comes not by fair means, then it comes by foul.”(Emerson, 1983, p.163)

The more pressing truth, the devastating truth, however, is that "line in nature is not found" (Emerson, 1979, p.62). Good turns into evil, or every gain is a loss. "Eternal compensation" means that every good thing has a "dark side" (Emerson, 1979, p.63). The nature of things is that "the varieties of condition tend to equalize themselves. There is always some leveling circumstance that puts down the overbearing, the strong, the rich, the fortunate, substantially on the same ground with all others." (Emerson, 1979, p.63)

This is a teaching of futility, or almost is. The futility here is not that which Emerson takes up in Experience, namely the frustration involved in attempting to touched experience and be experienced. Rather the effort to surpass oneself constantly, the effort to discover always new powers in oneself and to remain unpredictable to oneself, may lead one into self-repetition. It seems that progressive indefiniteness may only be a lifelong recurrence of the same, of going around in a circle. Defeat awaits every exertion, because every exertion has something inaccurate, excessive, in it "Every excess causes a defect, every defect causes excess" (Emerson, 1979, p.66). The circle of defect and excess seems close. Audacity is born to fail. Experimentation tends to the presumptuous because it is entwined with self-ignorance. The failure lies not only in natural impermanence but also in irresistible self-condemnation. Really, the will to succeed encloses a will to fail, and not only because one grows impatient with success. Even in Circles, Emerson points to the underside of the will to succeed: "The great moments of history are the facilitator of performance through the strength of ideas, as the works of genius and religion. 'A man,' said Oliver Cromwell, 'never rises so high as when he knows not whither he is going. Dreams and drunkenness, the use of opium and alcohol are the semblance and counterfeit of this oracular genius, and hence their dangerous attraction for men. For the like reason they ask the aid of wild passions, as in gaming and war, to ape in some manner these flames and generosities of the heart." (Emerson, 1979, p.414)

These words come right after the great sentence on abandonment and conclude the essay. But I find that they almost cancel the preceding celebration. The line between inspired abandonment and mere delirium is made faint. The circumstance to which Emerson points in order to explain the setbacks of exceptional exertion may finally be as much inside the person as in the constitution of the universe. Anyway, experimentation can become exhausting. Indefiniteness 
may be too great a burden, or the wrong kind of burden, for the actively self-reliant individual to carry. The likely result, much more often than not, would be to find oneself lost in semblances and counterfeits of enlarging movement, with wild passions only aping the sincerity of self-pursuit. Why make yourself the work of your life? Why not make work the life of yourself? These questions are force on us by Emerson's theory of compensation, but may not be answered by it.

\section{B. Individual's Life Should Have Periods or Moods of Abandonment}

No matter what one may say, however, about the precariousness of Emerson's commitment to the idea of active self-reliance as indefinite motion outwards, as change in the boundaries of identity, it is not rejected. And individual's life should have periods or moods of abandonment. Abandonment is best when fitful-then one is truly overcome. But Emerson has yet another idea of active self-reliance that I think he ranks higher than this one-in fact, ranks as the highest one of all in his writings: the idea of active self-reliance as finding and doing one's work. To be who you are is to pursue not an endless experiment but your vocation: "In pursuing one's vocation, one most certainly acts as an individual, as oneself, and also makes the greatest contribution to others, even if not always or not even usually mindful of one's work as a contribution, but rather thinking that in caring for one's work, one is caring for oneself as an object worthy of care, and caring for oneself nonegotistically. Let it be said that Emerson lived life as vocation: he remained as true to his vocation as anyone could desire while refusing experiments in living." (Kateb, 1995, p. 180)

One's work comes out of a purposive but not experimental or adventurous unfolding of one's powers. "By doing his own work he unfolds himself' (Emerson, 1979, p.78). Powers should be concentrated in the work one does. One stays with one's work; one does not abandon it after finding it, though abandonment to it is essential to performance. In doing one's work, one goes some way toward uniting what is most deeply present in oneself with what is most resistantly present in the world, while constantly being aware of the difference and the distance between oneself and the world. "The world is inchoate until one works on it human exertion is needed to make the world known; the world responds to the effort; and powers or limits" (Emerson, 1973, p.113). One's work is one's double, not as a friend or lover is or maybe, but as a deliberate externalization. Emerson says "The common experience is that the man fits himself as well as he can to the customary details of that work or trades he falls into, and tends it as a dog turns a spit. Then it he a part of the machine he moves; the man is lost. Until he can manage to communicate himself to others in his full stature and proportion, he does not yet find his vocation." (Emerson, 1979, p. 81-82)

Self-reliant individuals cannot be moved by their machine. They must be self-moved, and thus move in their own direction until they find their work to do. Society may set up constraints to self-choice in occupations, and then be, for a while, insensitive to the results of one's effort. "The shame is that the world is full of involuntary work and hence waste and routine" (Emerson, 1973, p.114). But some are lucky and face the difficulties of vocation. By "doing his work he makes the need felt which he can supply and creates the tasted by which he is enjoyed" (Emerson, 1979, p.84). Persistence is necessary. Emerson is aware that temporary defections from one's work are likely. In a general formulation that appears in his discussion of vacation, he says: "We side with the hero, as well read or paint, against the coward and the robber; but we have been ourselves that coward and robber, and shall be again --- not in the low circumstances, but in comparison with the grandeurs possible to the soul" (Emerson, 1979, p.84). If determination is needed to find one's vocation and remain with it, the rewards are immense. One shares the attribute of what Emerson calls the "Supreme Cause", namely, self-existence; no one is literally self-authored. One's being is transmitted, returning to oneself as oneself, even though no result, perhaps, is ever good enough in itself or adequate to express the mere fact of the ability to do work and create what did not exist before. Emerson says: "Self-existence is the attribute of the Supreme Cause, and it constitutes the measure of good by the degree in which it enters into all lower forms. All things real are so by so much virtue as they contain. Commerce, husbandry, hunting, whaling, war, eloquence, personal weight, are somewhat, and engage my respect as examples of its presence and impure action." (Emerson, 1979, p.42)

\section{ANOTHER COMPLEX IDEA OF SELF-RELIANCE--VocATION}

\section{A. The Idea of Vocation--The Highest Form of Practical Self-reliant Activity}

Emerson says in Spiritual Laws that "Every man has this call of power to do somewhat unique, and no man has any other call" (1979, p.87). He tries to persuade his audience that each of us has something to do that is worth doing, and that if we do not do it, we die. Doing one's work until the end is the only linear forward movement; it is courage undamaged by the laws of compensation, unlike the audacities of immeasurable credulity inherent in always trying to draw a greater circle than the last one. "There is no tax on the good of virtue" (Emerson, 1979, p.68). The immense cost of doing one's own work counts for nothing because no price can be placed on being oneself.

The idea of vocation is therefore the highest form of practical self-reliant activity. Work is one's work but ones' work is also work on the self. Work exceeds the play, if you will, magnificently urged in Circles. And it is free of the contaminations of egotism or its simulacrum that afflict the projects of pursuing wealth and political power and social standing. I do acknowledge, however, that Emerson sometimes depicts these worldly pursuits also as vocations. But his characterizations of one's vocation as the work that emerges out of one's uniqueness do not typically correspond to worldly exertions, which are impure or low, or ruled by the world's discipline. What then are the best vocations?

Emerson blends divinity and humanity, divine creation and human works, celebration and discontent, in a few lines. 
Thus, as with God, an individual's performance never ideally represents the performer. Yet if Emerson is to satisfy himself that self-reliance can show itself in enactment, then vocation, thought apparently always "impure action" (Emerson,1979, p.416), is the best way.

A person's vocation is the work that one can do well or do better than others can, or it is the work that no one else can do. Emerson's formulations vary. "There is one direction to every man in which unlimited space is open to him. He finds obstruction an all sides but one" (Emerson, 1972, p.1003). At the same time, he seems insistent that there is something to do that best suits each of us. What is best for us is therefore best for our work. "Society can never prosper," Emerson says, "but must always be bankrupt, until every man does that which he was created to do" (Emerson, 1972, p.1003). And neither can the individual prosper. Unless one does the right work one would not attain the human status. Persons must have a conscious feeling of their necessity if their existence is to be justified in their own eyes. Again, it is not that they must feel useful to others. That sentiment would only make them into instruments. Nor is it the case that their work must directly contribute to the world's welfare. But it must be work free of triviality. "Whatever games are played with us, we must play no games with ourselves" (Emerson, 1972, p.1122).

One must not let one's forces be scattered. By concentration one becomes distinctive. If the doctrine, the doctrine of vocation, entails that narrowness is necessarily involved in concentration, and that concentration surpasses continuous experimentation. Concentration is the best transmutation of one's incurable limitedness of sensibility and capacity to experience. "If you ask what compensation is made for the inevitable narrowness, why, this, that in learning one thing well you learn all things" (Emerson,1973, p.51). Though each person is "a partialist" (Emerson, 1973, p.51) in doing what he or she does through a "self-conceit" (Emerson, 1973, p.51), every person is also justified in such individuality because each is of an immense nature. "And now I add," Emerson says, "that every man is a universe also" (Emerson, 1973, p.51). "As our earth, whilst it spins on its own axis, spins all the time around the sun through the celestial spaces, so the least of its rational children, the most dedicated to his private affair, works out, though as it were under a disguise, the universal problem" (Emerson, 1983, p.214-215).

No account of Emerson's idea of vocation can, however, omit mention of the striking reflection on the division of labor in The American Scholar. It is not so much a counterweight to the idea of vocation as a reminder that, after all, contrary to the reassurances given, narrowness is narrowness. Emerson admires versatility because the division of labor has become so special that "if anything gets out of order," the workman is "helpless to repair it" (Emerson, 1975, p.48). "Now that the machine is so perfect, the engineer is nobody" (Emerson, 1975, p.49). An ancient fable instructs us, he says, that originally there was Man, not men, but the gods divided Man into men so that "he might be more helpful to himself." Now "You must take the whole society to find the whole man" (Emerson, 1975, p.53-54).

How does each one of us become whole again, become Man doing this or that, rather than remain an embodied function? Emerson does not give us an answer. Only when each of us is thinking is each of us Man. To be a professional thinker, however, is not the same as having the vocation of the hope that a worker in the world will, b an act of reconception, give "an ideal worth to his work" (Emerson, 1975, p.54) and not be "ridden by the routine of his craft" (Emerson, 1975, p.54) or allow his soul to be "subject to dollars" (Emerson, 1975, p.54)

The narrowness of one's work, in any case, reflects the fact that a person's very uniqueness or genius - the peculiar quality that differences him from every other - is "a selecting principle" (Emerson, 1975, p.57). Emerson refers to "that mysterious emphasis" (Emerson, 1975, p.57) that each person places on all events and situations and hence on his memory, and that "quite without any effort of his will" (Emerson, 1975, p.57) determines the choices of his life.

Notice that the work is dear to God, which can be another way of saying that the standard of usefulness is not directly social or even moral. The work contributes to preserving the sense of the world's possibilities, and it is a manifestation of what any one human being s capable of. Beyond that lies the simple principle, individualistic and not quiet egotistical notion that from doing work for its own sake one will derive a supreme pleasure. Emerson makes his point in two rhetorical questions: "is there no loving of knowledge, and of art, and of our design, for itself alone? Cannot we please ourselves with performing our work, or gaining truth and power, without being praised for it?" (Emerson, 1972, p.294)

\section{B. The Basis of Emerson's View of Vocation--Allowing One to Live Properly with Oneself}

The basis of Emerson's view of vocation, as already indicated, is that every individual is unique. It is one's uniqueness that makes one indispensable to others, and irreplaceable, simultaneously allowing one to live properly with oneself. From one's uniqueness as an individual flows the uniqueness of one's work. Emerson formulates our newness in this way: "Every man, with whatever family resemblances, has a new countenance, new manner, new voice, new thoughts, and new character. Whilst he shares with all mankind the gift of reason, and the moral sentiment, there is a teaching for him from within, which is leading him in a new path, and, the ore it is trusted, separates and signalizes him, while it makes him more important and necessary to society. We call this specialty the bias of each individual. And none of us will ever accomplish anything excellent or commanding except when he listens to this whisper, which is heard by him alone." (Emerson, 1983, p 356-357)

The wise man ever finds himself conscious of knowing nothing but being just ready to begin to know. He is as if just born and ready to ask the first question. It is only when we persist in our work that we disclose our originality. "But there remains the indefeasible persistency of the individual to be himself. Every mind is different and the more it is unfolded, the more pronounced is that difference, and what is originality? It is being one's self, and reporting accurately what we see and are." (Emerson, 1983, p.360) 
Emerson is trying to democratize greatness: "Greatness, -- what is it? Is there not some injury to us, some insult in the word? What we commonly call greatness is only such in our barbarous or infant experience" (Emerson, 1983, p.362)

The truly great are not the famous warriors. Greatness is faith in one's uniqueness; such faith is self-respect is the early form in which greatness appears" (Emerson, 1983, p.363). I must point out that whereas mental self-reliance requires only being "a guest" in one's own thought, active self-reliance in the form of vocation requires one to be at home with oneself. This difference of imperatives is another indication of the superiority of mental to active self-reliance.

It is hard to infer Emerson's meaning. "The soul," he says, "strives remain to live and work through all things. It would be the only fact" (Emerson, 1979, p.69). At the limit, this means that one transforms the world by one's activity in it. One remakes it in one's image. Who has come closest to doing so? Emerson's answer seems to be Jesus, though he does not name him in this context. About the life of Jesus, he says, "This great defeat is hitherto our highest fact." But Emerson contends, "the mind requires a victory to senses" (Emerson, 1979, p.69). Force of character would convert "judge, jury, soldier and king” (Emerson, 1979, p.69). But such strength not even Jesus had. What then? Emerson gives the prize to Jesus, nevertheless. "When that love which is all-suffering, all-abstaining, all-inspiring, which has vowed to itself that it will be a wretch and also a fool in this world sooner than soil its white hands by compliances, comes into our streets and house - only the pure and aspiring can know its face, and the only compliment they can pay it is to own it." (Emerson, 1971, p.32)

Jesus is the model of faithfulness in vocation, but he is hardly a model any of us can expect to follow, not because he is divine but because he is humanly perfect, not all-too-human. That aspect, too, is part of his defeat. Perhaps Emerson's teaching is that defeat is the inescapable destiny of activity in the world? No, that is not what he wants us to take as his final meaning, though it maybe what he feels. He says: "My work may be of none, but I must not think it of none, or I shall not do it with impunity. In like manner, there is throughout nature something mocking, something that leads us on and on, but arrives nowhere, keeps no faith with us. All promise outruns the performance." (Emerson, 1971, p.33-34)

It is hard to say what Emerson leaves for self-reliant work, given this radical dissatisfaction. What does it mean for a person to be all here?

The trouble is that his descriptions of vocation usually seem to make the most sense when they are read as referring to mental activity, which was Emerson's own vocation. Individual uniqueness is one's special power to see and to say; it is a power of observation and distillation. It is as if true expressiveness could only be mental, and what one expresses is not oneself but the world in which one finds oneself. We exist to produce the best possible sentences, to say the world as unegotistically or impersonally as possible; yet inevitably, and desirably, each one is new and meets the new. What we express comes out as a perspective. Each one of us has "some incommunicable sagacity" (Emerson, 1973, p.32). The incommunicable must inform the communicated.

I know that it may be exasperating to keep returning to mental activity as the only real domain of self-reliance. But I think that this is the point Emerson always makes in many different ways. Everyone's vocation is to philosophize. Nothing is like it. The gulf between success in thinking and success in doing is vast because the world is too hard for self-reliance to be shown with much success in anything but mental activity; yet the world is, of course, inconceivably wondrous and hence worth the exertions, which self-reliant mental activity makes, to receive and affirm it, and to do so being aware of its uncorrectable imperfections. But I do not intend to efface the significance for Emerson of active self-reliance. The temptation to efface it must be resisted by us just as strenuously as Emerson tries to resist it. Many kinds of engagement with the world certainly do show traces and more than traces of the qualities he thinks proper to self-reliant individuals. And the best activities will be those that the more they are pursued as vocations the more gratifying they become. They are the most real to the self and help to make the self feel most real.

I propose that mental self-reliance - thinking one's thoughts and thinking them through in the modes of perception, contemplation, and retrospection - is the model of active self-reliance. Acting self-reliantly is analogous to thinking self-reliantly. The link comes from the idea that thinking is close to prayer, is like prayer. But action can also be like prayer. In Self-reliance, Emerson says that it is open to us to see "prayer in all action" (Emerson, 1979, p.47). The prayer of the farmer kneeling in his field to weed it, the prayer of the rower kneeling with the stroke of his oar, are true prayers heard throughout nature, though for cheap ends" (Emerson, 1979, p.48). I here make use of this formulation, cited before, to suggest that any activity, any work, when done like prayer - when done after the model of concentrated self-reliant thinking - can be a vocation, even if it has no philosophical thinking in it, even if the thinking it contains is only practical thinking, even if it is done for meaningless ends. Similarly, any work can be done poetically. In words to which I have also already referred, Emerson suggests that any craft or trade can be "handled poetically" (Emerson, 1983, p.168), which means that the worker stands superior to facts and masters them, rather than "apprehending them through a sense of their beauty" (Emerson, 1983, p.168). Doing one's own works on and cares for oneself just by working for the sake of the work. One's work becomes oneself.

Finally, perhaps Emerson's suggestion is that one's ideal vocation is to build one's character and remain true to it for as long as possible. This work on the self does not proceed by continuous experiment or adventure but by an ever more intense search for integrity. "Be what your are" (Emerson, 1972, p.1122) is a precept of self-consistency amid tremendous resistances and obstacles, both in finding oneself and keeping oneself. The precept means that one should 
try to be "what cannot be skipped, or dissipated, or undermined" (Emerson, 1972, p.1122). If one is oneself and not a socially constructed collage, one's uniqueness is revealed. At the same time, one stands for something. The world always needs examples of integrity. In seeing character as vocation, we avoid excessive intellectualism and we also repel delusions about the chances of an objective, substantive, monumental achievement that is truly one's own. One's character may show itself in any particular activity that one chooses or is driven to take up as especially appropriate for ones unfolding in one's specific vocation. Work exists for the self, provided the work is done for its own sake and on its own best terms; but the self exists for more than work. One's character is one's manner of being, one's continuous style. To work on it is to refuse to think that one just exists, like a rose in bloom. One must work to persist as oneself. One neither invites nor declines challenge to one's integrity. Identity is discipline. One takes the world seriously by taking oneself seriously. One wants to be the best one can. One's character is an offering to the world in the sense that an example of self-search and self-finding is being presented. To interpret Emerson I can do no better than quote a passage from an interview Foucault gave a few months before his death. "Let us take for example Socrates. He is truly the man who cares for others. That is the particular position often philosopher. But let us say it simply: in the case of the free man, I think one can say that the Greek who cares for himself should first of all care for others. One must not have the care of others precede the care for the self. The care of self takes moral, precedence in the measure that the relationship to self takes ontological precedence. (Howe, 1986, p.7)

\section{REFERENCES}

[1] George Kateb. (1995). Emerson and Self-reliance. Cambridge: the Riverside Press.

[2] Ralph Waldo Emerson. (1971). Nature. The Collected Works of Ralph Waldo Emerson. Volume I. Ed. Joseph Slater. Cambridge: Harvard University Press.

[3] Ralph Waldo Emerson. (1979). Circles. The Collected Works of Ralph Waldo Emerson. Volume II. Ed. Joseph Slater. Cambridge: Harvard University Press.

[4] Ralph Waldo Emerson. (1983). Politics. The Collected Works of Ralph Waldo Emerson. Volume III. Ed. Joseph Slater. Cambridge: Harvard University Press.

[5] Ralph Waldo Emerson. (1983). Nominalist and Realist. The Collected Works of Ralph Waldo Emerson. Volume III. Ed. Joseph Slater. Cambridge: Harvard University Press.

[6] Ralph Waldo Emerson. (1983). Greatness. The Collected Works of Ralph Waldo Emerson. Volume III. Ed. Joseph Slater. Cambridge: Harvard University Press.

[7] Ralph Waldo Emerson. (1979). Compensation. The Collected Works of Ralph Waldo Emerson. Volume II. Ed. Joseph Slater. Cambridge: Harvard University Press.

[8] Ralph Waldo Emerson. (1972). The Conduct of Life. Cambridge: Harvard University Press.

[9] Ralph Waldo Emerson. (1972). Society and Solitude. Cambridge: Harvard University Press.

[10] Ralph Waldo Emerson. (1975). The American Scholar. Cambridge: Harvard University Press.

[11] Ralph Waldo Emerson. (1973). Trades and Professions. Emerson's Complete Works, Vol.XII. Ed. Douglas Emory Wilson. Cambridge: the Riverside Press.

[12] Ralph Waldo Emerson. (1973). Natural History of Intellect. Emerson's Complete Works, Vol.XII. Ed. Douglas Emory Wilson. Cambridge: the Riverside Press.

[13] Ralph Waldo Emerson. (1979). Spiritual Laws. The Collected Works of Ralph Waldo Emerson. Volume II. Ed. Joseph Slater. Cambridge: Harvard University Press.

[14] Ralph Waldo Emerson. (1979). Self-reliance. The Collected Works of Ralph Waldo Emerson. Volume II. Ed. Joseph Slater. Cambridge: Harvard University Press.

Haijing Liang was born in Suiling, Heilongjiang Province, China in 1979. She received her M.A. degree in British and American literature from Haerbin Engineering University, China, in 2005.

She is currently a lecturer in the School of Foreign Languages, Qingdao University of Science and Technology, Qingdao, China. Her research interests include British and American literature. 